\title{
PERANAN GURU DALAM PENGELOLAAN KELAS
}

\author{
Oleh: Nurhalisah*
}

\begin{abstract}
Classroom is an important meeting room between students and teachers in teaching process, where teachers transfer their knowledge to students. Flexible class management is important and teachers play an important role in this respect. Skill of class management is important to stimulate student to be productive and dinamic. Moreover, teachers face students who have different cultural background. Diversity does not always means some students are left behind and some are more developed. Instead, diversity is a contributing factor to studens for a change individually.
\end{abstract}

KEYWORDS: Pengelolaan kelas, guru, peserta didik

KELAS selamanya menjadi perbincangan menarik, ada guru tertentu (pelaku pendidikan) memanfaatkan kelas sebagai tempat pelampiasan, kemarahan dan keluh kesah yang terjadi sebelum memasuki kelas. Guru tampil sebagai seorang superior yang harus ditakuti dan ditaati apapun perlakuan yang dilakukan di dalam kelas. Hal tersebut memungkinkan terjadi pada kelas-kelas tertentu, terutama pada kelas belajar yang tidak terpisahkan dengan pembelajaran kekerasan sebagai bagian dari bangunan dan penguatan mental. Kelas adalah tempat berlangsungnya transformasi pengetahuan dan pembentukan kepribadian peserta didik. Kelas juga menjadi penting terutama bagi guru (pengajar), sebagai tempat melakukan koreksi diri baik yang berhubungan dengan penguasaan materi ajar, pemanfaatan media pembelajaran secara maksimal juga dapat berkaitan dengan pendekatan personal dan kolektif yang dilakukan guru dalam proses pembelajaran.

Ilmu pengetahuan sebagai kerangka perubahan peserta didik, memiliki makna implisit yang dapat berfungsi perubah apabila keberlangsungannya dalam suasana kondusif. "perubahan pada aspek pengembangan pribadi, pengembangan warga Negara, pengembangan kebudayaan, dan pengembangan bangsa" ${ }^{1}$

*Magister Manajemen Pendidikan dari Universitas Negeri Makassar ini adalah dosen tetap pada Fakultas Tarbiyah dan Keguruan UIN Alauddin Makassar. 
Pengembangan pendidikan yang syarat dengan dinamika menuntut adanya reformulasi sebagai arah baru pendidikan. Reformulasi atau paradigma pendidikan dikenal dengan paradigma organik yang selamanya bertumpu pada interaksi dalam kelas. Sekolah tidak hanya dilihat sebagai proses mekanik akan tetapi sebagai sistem organik ${ }^{2}$ yang bertujuan untuk mengembangkan diri peserta didik secara utuh dengan kemampuan intelektual, personal dan sosial. Suatu kelas adalah merupakan bangunan dari berbagai interaksi, baik interaksi akademik maupun interaksi non akademik, termasuk interaksi guru dengan peserta didik yang bersifat formal melalui proses belajar mengajar, interaksi peserta didik dengan pegawai administrasi, pegawai perpustakaan dan lain sebagainya. Hal ini menunjukkan bahwa di sekolah selalu berlangsung kerjasama dan diperlukan suatu sistem yang mengkoordinasi dan mensinerjikan seluruh interaksi yang ada disekolah.

Interaksi akademik berupa; 1 . Interaksi guru dalam menjelaskan materi, 2.interaksi guru dalam mengajukan pertanyaan, dan 3. Interaksi guru dalam memberikan tanggapan atau jawaban terhadap pertanyaan peserta didik ${ }^{3}$ memberikan implikasi terhadap perkembangan kemampuan peserta didik baik yang berhubungan dengan kapasitas personalnya maupun kematangan sosialnya. Interaksi yang baik bukan berlangsung secara alamiah akan tetapi melewati penataan diri menjadi lebih baik yang secara implisit dan eksplisit memberikan pengaruh terhadap peserta didik. Hal penting yang harus diubah oleh guru adalah sudut pandang dari memahami peserta didik sebagai obyek pengajaran menjadi peserta didik menjadi subyek pengajaran. Selain itu, guru harus melahirkan kepercayaan yang tinggi terhadap peserta didik, guru menunjukan tindakan konsisten dan reputasi pribadi yang baik, meyakini segi terbaik dan positif dari peserta didik, mengkomunikasikan segala sesuatu sesuatu dengan harapan peserta didik dan memperlakukan peserta didik secara terhormat. ${ }^{4}$ Oleh karenanya menurut hemat penulis sekolah terutama kelas sebagai tempat utama harus dikelola dengan baik oleh guru sehingga menjadi tempat yang menyenangkan menerima ilmu pengetahuan dan tempat menyalurkan segala bentuk kreasi peserta didik.

\section{PENGERTIAN PENGELOLAAN KELAS}

Fokus dalam mengelola kelas adalah siswa. Pengelolaannya dititik beratkan pada keragaman berupa perbedaan latar belakang peserta didik, perbedaan kemampuan dan kecenderungan yang dimiliki siswa atau berkaitan dengan sikap belajar siswa. Sikap peserta didik dalam proses belajar, merupakan bahagian penting yang harus diperhatikan karena 
aktivitas belajar banyak ditentukan oleh sikap belajar peserta didik. Ketika memulai kegiatan belajar peserta didik memiliki sikap menerima atau ada kesediaan emosional untuk belajar, maka peserta didik akan cenderung berusaha terlibat dalam kegiatan belajar dengan baik. Namun bilamana lebih dominan sikap menolak sebelum belajar, maka siswa kurang memperhatikan kegiatan pembelajaran.

Kelas sebagai tempat mendapatkan ilmu pengetahuan melalui transformasi yang dilakukan guru, harus berlangsung secara kondusif, dialogis, inovatif dan kritis sehingga pembelajaran bernuansa aktif, kreatif dan menyenangkan. Tugas utama guru selain penguasaan materi ajar, metodologi dan media pembelajaran juga harus mengelola kelas dengan baik. Kelas tidak akan berlangsung baik dan kondusif secara alamiah karena didalamnya beragam "karakter" 5 akan tetapi harus dikelola oleh guru secara baik. Guru sebagai penentu seluruh pergerakan kelas dapat menciptakan interaksi efektif apabila memperhatikan faktor-faktor yang mempengaruhi seperti; (1) penjabaran tujuan, (2) motivasi kepada siswa, (3) penggunaan model, (4) urutan materi, (5) pengaturan latihan secara efektif, (7) memahami perbedaan individu, (8) bantuan aplikasi hasil belajar. ${ }^{6}$

Pengelolaan kelas terdiri dari dua kata yaitu; Pengelolaan dan Kelas. Pengelolaan akar katanya dari kelola ditambah awalan pe dan akhiran an. Istilah lain dari pengelolaan adalah manajemen yang berarti ketatalaksanaan, tata pimpinan, dan pengelolaan. Pengelolaan dalam makna umum adalah pengadministrasian, pengaturan dan penataan suatu kegiatan. ${ }^{7}$ Kata kedua adalah kelas. "Kelas adalah suatu kelompok orang yang melakukan kegiatan belajar bersama, yang mendapat pengajaran dari guru"..$^{\prime \prime}$ Pandangan tersebut lebih berorientasi pada siswa karena menitikberatkan pada kelompok dan kegiatan bersama. Berarti di dalam kelas yang dimaksud adalah terdiri dari sejumlah peserta didik yang sedang menerima pengajaran dari seorang guru. Ada dua mata rantai yang tidak terpisah pada makna tersebut yaitu peserta didik dan guru.

Pandangan lain mengenai kelas seperti yang dikemukakan oleh Hadari Nawawi, kelas dapat dilihat pada dua sudut pandang yaitu kelas dalam arti sempit yakni, ruangan yang dibatasi oleh empat dinding, tempat sejumlah siswa berkumpul untuk mengikuti proses belajar mengajar. Kelas pada makna diatas lebih bersifat statis karena sekedar menunjuk pengelompokan siswa menurut tingkat perkembangannya yang antara lain didasarkan unsur kronologis masing-masing. Kelas dalam arti yang luas adalah suatu masyarakat kecil yang merupakan bagian dari masyarakat sekolah, sebagai satu kesatuan diorganisasi menjadi unit kerja yang dina- 
mis menyelenggarakan kegiatan-kegiatan belajar mengajar yang kreatif untuk mencapai suatu tujuan" "Pengelolaan Kelas adalah keterampilan guru untuk menciptakan dan memelihara kondisi belajar yang optimal dan mengembalikannya bila terjadi gangguan dalam proses belajar mengajar". ${ }^{10}$

Pengelolaan pada makna di atas menjadi penting, pada sisi peserta didik, merupakan aktivitas kejiwaan yang melibatkan banyak komponen agar seluruh aktivitas kejiwaan bersinerji dan berfungsi optimal. Aktivitas jiwa didasarkan pada jiwa sebagai kekuatan penting terutama dalam kegiatan belajar. Kualitas pembelajaran dengan konsentrasi dan perhatian yang tinggi sebagai bahagian utama akan kesempurnaan pemahaman peserta didik terhadap materi ajar. Jiwa manusia memiliki tiga kekuatan yaitu; 1) Akal sebagai kekuatan terpenting dari jiwa manusia, akal adalah bahagian jiwa manusia yang merupakan kekuatan untuk menemukan kebenaran dan kesalahan. Dengan akal manusia dapat mengarahkan seluruh aktivitas jasmani dan kejiwaannya sehingga manusia mampu memperoleh kehidupan yang lebih sejahtera, 2) Spirit sebagai kekuatan penggerak kehidupan pribadi manusia. Spirit adalah kekuatan untuk menjalankan gagasan-gagasan, 3) Nafsu sebagai stimulasi gerakan fisik dari kejiwaan dan merupakan kekuatan paling konkret dalam diri manusia. Nafsu terbentuk dari sejumlah keinginan dan selera yang erat hubungannya dengan fungsi jasmani. ${ }^{11}$

Pembelajaran dalam kelas, harus mendapat perlakuan yang baik dari seorang guru dengan membangun pengertian sempurna terhadap peserta didiknya dari segala aspek termasuk aspek kejiwaan. Belajar akan berlangsung baik apabila (1) pengindraan terjadi apabila obyek eksternal berinteraksi dengan organ indra, (2) perasaan sangat erat hubungannya dengan pengindraan (3) keinginan sangat erat kaitannya dengan perasaan senang atau tidak senang, cocok atau tidak cocok, setuju atau tidak setuju, (4) kemauan sangat erat hubungannya dengan keinginan. Belajar sangat erat hubungannya dengan pengaruh internal peserta didik berupa aktivitas kejiwaan dengan lingkungan belajar yang menyenangkan.

Bila guru berada dalam kelas, memiliki dua tugas utama yaitu mengajar dan manajemen. Mengajar maksudnya adalah usaha membantu peserta didik dalam mencapai tujuan pengajaran. Bantuan guru berupa membuat rencana pengajaran, menyajikan informasi, mengajukan pertanyaan, dan melakukan evaluasi pengajaran. Pandangan lain tentang mengajar adalah "menyampaikan pengetahuan kepada peserta didik di sekolah, usaha organisasi lingkungan sehingga menciptakan kondisi belajar bagi peserta didik. Belajar juga bermakna kegiatan mempersiapkan 
siswa untuk menjadi warga Negara yang baik sesuai dengan tuntutan masyarakat"12 Sedangkan yang berhubungan dengan fungsi guru sebagai manajerial adalah usaha untuk menciptakan dan mempertahankan kondisi sedemikian rupa sehingga proses belajar mengajar dapat berlangsung secara efektif dan efisien. Kondisi belajar yang efektif berupa pemberian penguatan, mengembangkan hubungan guru dengan peserta didik dan membuat aturan kelompok yang produktif.

Setiap guru berusaha maksimal, agar kelas dapat dikelola dengan baik. Pengelolaan yang baik didasarkan pada; Pertama, guru mengetahui secara cepat faktor-faktor yang menunjang terciptanya kondisi yang menguntungkan dalam proses pembelajaran, Kedua, dikenal masalah-masalah yang diperkirakan dan biasanya muncul dan dapat merusak iklim pembelajaran, Ketiga, dikuasainya berbagai pendekatan dalam pengelolaan kelas dan diketahui pula kapan dan untuk masalah mana pendekatan yang digunakan.

Pengelolaan kelas bukan bermakna pasti selalu terkait dengan masalah, akan tetapi lebih bermakna pengaturan kelas untuk kepentingan pengajaran. Pengelolaan kelas juga berarti keterampilan guru untuk menciptakan iklim pembelajaran yang kondusif dan mengendalikannya jika terjadi gangguan dalam pembelajaran. ${ }^{13}$ Kelas ketika dikelola baik akan menimbulkan; 1) kehangatan dan antusiasme pembelajaran, 2) menantang, 3) bervariasi, 4) luwes, 5) penekanan pada hal-hal yang positif, 6) penanaman disiplin diri, dan 7) dialogis. Selain itu kelas dikelola dengan memperhatikan komponen-komponen tertentu yaitu; Pertama, menciptakan dan meme-lihara iklim pembelajaran yang optimal seperti; a) menunjukan sikap tanggung jawab dengan cara memandang secara seksama, mendekati dan memberikan pernyataan, reaktif terhadap gangguan di kelas, b) membagi perhatian secara visual, c) memusatkan perhatian kelompok dengan cara menyiapkan peserta didik dalam pembelajaran, d) memberikan petunjuk yang jelas, e) memberikan teguran secara bijaksana, f) memberikan penguatan ketika diperlukan.

Kedua, keterampilan yang berhubungan dengan pengendalian kondisi belajar yang optimal dengan cara a) modifikasi perilaku dengan mengajarkan perilaku baru dengan contoh dan pembiasaan, meningkatkan perilaku yang baik melalui penguatan dan mengurangi perilaku buruk dengan hukuman, b) pengelolaan kelompok dengan cara meningkatkan kerja sama dan keterlibatan serta menangani konflik dengan memperkecil munculnya masalah baru, c) menemukan dan mengatasi perilaku yang menimbulkan masalah dengan pendekatan; (1) pengabdian yang direncanakan, (2) campur tangan dengan isyarat, (3) mengawasi secara ketat, (4) me- 
ngakui perasaan negatif peserta didik, (5) mendorong peserta didik mengungkapkan perasaannya, (6) menjauhkan benda-benda yang dapat mengganggu konsentrasi, (7) menyusun kembali program belajar, dan (8) menghilangkan ketegangan dengan cara humor.

Pengelolaan kelas lebih menekankan pada "seleksi dan penggunaan alat-alat yang tepat terhadap problem dan situasi kelas". ${ }^{14}$ Hal tersebut berarti guru bertugas menciptakan, memperbaiki, dan memelihara sistem dan segala hal yang berkaitan dengan pembelajaran. Sehingga peserta didik dapat memanfaatkan kemampuan dan bakatnya untuk tugas-tugas individu.

Alur pikir yang dikembangkan menunjukkan bahwa pengelolaan kelas dan pengelolaan pembelajaran adalah dua kegiatan yang sangat erat hubungannya, namun dapat dibedakan satu sama lain karena tujuan yang berbeda. Pengelolaan pembelajaran mencakup semua kegiatan yang secara langsung dimaksudkan untuk mencapai tujuan khusus pembelajaran berupa; menyusun rencana pembelajaran, memberi informasi, bertanya, dan menilai. Sedangkan pengelolaan kelas menunjukan kepada kegiatankegiatan yang menciptakan dan mempertahankan kondisi yang optimal bagi terjadinya proses pembelajaran. Menghentikan perilaku peserta didik yang menyeleweng perhatian kelas, pemberian ganjaran bagi ketepatan waktu penyelesaian tugas dengan penetapan norma kelompok yang produktif.

Pengelolaan kelas sangat diperlukan selain keragaman potensi dan kemampuan setiap peserta didik juga fenomena kelas dapat berubah setiap saat. Pada hari tertentu suasana belajar tenang, kondusif dan efektif, persaingan prestasi menjadi dominasi dalam kelas, kelas selalu dinamis dalam bentuk perilaku, perbuatan, sikap mental dan emosional peserta didik. Pada waktu yang lain dapat merubah iklim prestasi tidak menjadi dominan karena ada faktor-faktor tertentu yang mempengaruhi sikap mental peserta didik.

Masalah-masalah yang muncul sehingga harus dilakukan pengelolaan kelas seperti; 1) kurang kesatuan, 2) tidak ada standar perilaku, 3) reaksi negatif terhadap anggota kelompok, 4) kelas mentoleransi kekeliruan temannya, menerima dan mendorong perilaku anak yang keliru, 5) mudah mereaksi kepada hal-hal yang negatif, 6) moral yang rendah, permusuhan, dan agresif, 7) tidak mampu menyesuaikan dengan lingkungan yang berubah.

Berdasarkan alur pikir di atas, dapatlah dipahami bahwa pengelolaan kelas lebih bermakna Pertama, sekelompok anak, walaupun dalam waktu yang sama bersama-sama menerima pelajaran, tetapi bukan pelajaran yang 
sama dari guru yang sama, namanya bukan kelas, Kedua, sekelompok anak yang dalam waktu yang sama menerima pelajaran yang sama, tetapi guru yang berbeda, namanya juga bukan kelas, Ketiga, sekelompok anak yang sama, menerima pelajaran yang sama dari guru yang sama, tetapi jika pelajaran tersebut diberikan secara bergantian, namanya juga bukan kelas. Karena itu kelas semacam suasana komprehensif yaitu pengajaran yang berlangsung pada waktu sama, guru yang sama dan pelajaran yang sama. Pemikiran tersebut dalam rangka mewujudkan pembelajaran yang profesional yang dimainkan oleh guru sehingga pembelajaran memiliki makna terhadap peserta didik.

\section{TUJUAN PENGELOLAAN KELAS}

Kelas dikelola bukan hanya dengan superioritas seorang guru, akan tetapi menjadi media penting untuk menyalurkan berbagai macam kemampuan dan keterampilan yang dihasilkan peserta didik, dapat melahirkan kreasi-kreasi baru sebagai efek interaksi guru dengan peserta didik. Bila guru ingin menjadi unggul maka harus memiliki ciri-ciri yaitu; 1) memiliki fisik dan mental yang kuat, 2) memiliki kepercayaan diri yang kuat, 3) bisa melayani pembelajaran secara baik, 4) selalu berpikir ke masa depan, 5) amanah, memiliki motivasi kerja yang tinggi, 6) senantiasa mengembangkan potensi diri, 7) banyak inisiatif dan kreatif, 8) memiliki gairah hidup yang tinggi, 9) memiliki loyalitas yang tinggi. ${ }^{15}$

Kapasitas dan sikap guru harus dialogis dan inovatif. Peserta didik memahami bahwa guru adalah tempatnya menemukan sesuatu yang baru baik yang berhubungan dengan ilmu pengetahuan, keterampilan maupun sikap hidup dalam berinteraksi. Kehadirannya didalam kelas menjadi kebanggaan dan daya tarik tersendiri. Sikap-sikap seperti di atas akan dapat mewujudkan tujuan pengelolaan kelas dengan baik dan sempurna.

Guru menyadari bahwa tanpa pengelola kelas dengan baik, akan menghambat kegiatan belajar mengajar. Loncatan berpikir bagi peserta didik menjadi target utama proses pengajaran. Peserta didik dari tidak tahu menjadi tahu, dari tidak tidak mengerti menjadi mengerti dan dari tidak berilmu menjadi berilmu. Tentu saja hal tersebut tercapai apabila guru berada dalam kelas dengan suasana yang menyenangkan memungkinkan para peserta didik dapat melatih dan mengembangkan kemampuannya.

Adapun tujuan pengelolaan kelas adalah menyediakan fasilitas bagi bermacam-macam kegiatan belajar peserta didik, dalam lingkungan sosial, emosional, dan intelektual dalam kelas ${ }^{16}$ selain itu tujuan pengelolaan kelas 
adalah agar setiap peserta didik dapat bekerja dengan tertib sehingga segera tercapai tujuan pengajaran secara efektif dan efisien. ${ }^{17}$

Kelas yang tertib artinya setiap peserta didik terus bekerja tidak ada anak yang terhenti bekerja karena tidak tahu. Setiap peserta didik terus bekerja tanpa membuang waktu, artinya setiap peserta didik akan bekerja secepatnya supaya cepat selesai tugas yang diberikan oleh guru. Bekerja dianggap sebagai tempat kreasi, membangun kerjasama diantara peserta didik, pada tingkat yang lebih tinggi dijadikan sebagai ajang lomba prestasi di antara mereka.

\section{KETERAMPILAN PENGELOLAAN KELAS}

Pengelolaan kelas menjadi perhatian yang sangat serius bagi pelaku pendidikan. Menariknya karena segala proses pembelajaran berlangsung dikelas. Perilaku yang ditampilkan seorang guru dalam berinteraksi dengan peserta didiknya menjadi lebih penting dalam proses pengajaran. Terdapat suatu iklim, guru tidak menghargai kebebasan peserta didiknya. Padahal yang menjadi fokus pembelajaran adalah pemberdayaan potensi yang dimiliki peserta didik. "Pendidikan yang membebaskan merupakan pendidikan yang mengkondisikan siswa untuk mengenal dan mengungkapkan kehidupan senyatanya secara kritis"18 Pendidikan yang membebaskan tidak dapat mereduksi menjadi sekedar usaha guru untuk memaksakan kebebasan kepada siswa. Sementara itu pendidikan yang membelenggu berusaha menanamkan kesadaran yang keliru kepada siswa sehingga mereka mengikuti alur kehidupan dan menerima realitas tanpa filter yang selektif.

Terlepas dari apakah kehadiran guru di kelas dan di luar kelas membebaskan atau membelenggu peserta didik. Kebutuhan dan tuntutan masyarakat akan tenaga kependidikan, terutama guru amat terasa esensi dan urgen dalam pendidikan formal untuk setiap jenis dan jenjang pendidikan. Di lembaga pendidikan formal, guru menjalankan tugas pokok dan fungsi yang bersifat multi peran yaitu; guru sebagai sumber belajar, pendidik dan agen perubahan.

Pertama, guru sebagai sumber belajar merupakan peran yang sangat penting terutama yang berkaitan erat dengan penguasaan materi pelajaran. Disebut sebagai guru yang baik apabila guru menguasai materi ajar. Terdapat kemudahan mengkomunikasikan materi ajar yang disampaikan oleh guru dengan peserta didiknya. Dinamika kelas akan sangat berkembang dari cara guru memainkan kelas dengan baik. Pertanyaan dari seorang peserta didik dapat dijawabnya dengan memuaskan, meluaskan pengetahuan peserta didik, dan menajamkan norma ilmu yang ditransformasikan. 
Seorang guru dianggap terampil dalam bidang ini apabila dapat menjalankan hal-hal sebagai berikut yaitu; 1) menyusun rancangan program identifikasi, assessmen dan pembelajaran anak yang kesulitan belajar, 2) berpartisipasi dalam penjaringan, assesment dan evaluasi anak yang kesulitan, 3) berkonsultasi dengan para ahli yang terkait dengan menginterpertasi laporan pengajaran, 4) melaksanakan tes, baik dengan tes formal maupun informal, 5) menyusun program pendidikan yang bersifat individual, 6) mengimplementasi program pendidikan yang diindividualkan, 7) membantu anak dalam mengembangkan pemahaman diri dan memperoleh harapan untuk berhasil serta keyakinan kesanggupan mengatasi kesulitan belajar. ${ }^{19}$

Sangatlah dipastikan bahwa guru menjadi fokus dari proses pembelajaran, kelengkapan pembelajaran terencana dengan baik dan sistemik sebagai landasan penting dalam perubahan peserta didik secara menyeluruh. Pembelajaran tidak hanya dapat dipahami oleh sekelompok peserta didik tertentu, akan tetapi menjadi sumber bagi semua peserta didik dalam proses pembelajaran.

Kedua, guru sebagai pendidik. Guru memainkan peranan penting akan pembentukan kepribadian peserta didik. Oleh karenanya, guru harus memiliki standar kualitas pribadi yang mencakup tanggung jawab, berwibawa, mandiri dan disiplin. Berkaitan dengan tanggung jawab; guru harus mengetahui nilai, norma moral, dan sosial serta berusaha berperilaku dan berbuat sesuai dengan nilai dan norma-norma tersebut. Guru juga bertanggung jawab terhadap perilaku peserta didik dalam pembelajaran di sekolah dan kehidupan masyarakat. Berkenaan dengan wibawa; guru harus memiliki kelebihan dalam merealisasikan nilai spiritual, emosional, moral, sosial dan intelektual dalam pribadinya serta memiliki kelebihan pemahaman ilmu pengetahuan, teknologi dan bidang-bidang lain yang dapat dikembangkan.

Guru yang memiliki otoritas dalam pembelajaran harus mampu mengambil keputusan secara benar dan mandiri, terutama dalam pembelajaran dan pembentukan kompetensi serta bertindak berdasarkan kondisi peserta didik dan lingkungan sosialnya. Pengambilan keputusan harus cepat, cermat, tepat sehingga dapat menguntungkan semua peserta didik. Sedangkan disiplin dimaksudkan bahwa guru harus mematuhi berbagai peraturan dan tata tertib secara konsisten, atas kesadaran profesional, karena guru meyakini untuk mendisiplinkan peserta didik di sekolah terutama dalam kegiatan pembelajaran.

Ketiga, guru sebagai agen pembaharu. Manusia memiliki kemampuan untuk belajar dari orang lain. Dalam ilmu jiwa perkembangan makna 
tersebut sebagai rekapitulasi yaitu perkembangan jiwa sebagai pengulangan ringkas dari sejarah kehidupan umat manusia, ada persamaan dengan kehidupan kebudayaan mulai masa primitif. ${ }^{20}$ Manusia normal menerima pendidikan dengan memiliki kesempatan yang cukup, ia dapat mengambil bagian-bagian dari pengalaman melalui proses belajar serta prestasi manusia dan mewujudkan yang terbaik dalam kepribadian yang unik dalam jangka waktu tertentu. Manusia tidak terbatas pada pengalaman pribadinya, melainkan dapat mewujudkan pengalanman-pengalaman dari semua waktu dan dari setiap kebudayaan.

Modernisasi tidak hanya diwujudkan dalam bentuk karya tulis seperti buku-buku sebagai alat utama pembelajaran, melainkan dalam semua rekaman tentang pengalaman manusia. Tugas guru adalah menerjemahkan kebijakan dan pengalaman yang berharga ke dalam istilah atau bahasa modern yang akan diterima oleh peserta didik. Pada kenyataannya, semua pikiran manusia harus dikemukakan kembali di setiap generasi oleh para guru dengan berbagai perbedaan yang dimiliki secara individual.

Seorang peserta didik yang belajar sekarang, secara psikologi berbeda jauh dari pengalaman manusia yang harus dipahami, dicermati dan diwujudkan dalam pendidikan, ada perbedaan fenomenologis peserta didik dengan dinamika sosial dan perkembangan keilmuan yang berlangsung. Guru harus menjembatani perbedaan peserta didik, jika tidak maka hal ini dapat mengambil bahagian dalam proses belajar yang berakibat tidak menggunakan potensi yang dimiliki peserta didik. Tugas guru adalah memahami bagaimana perbedaan dan bagaimana menjembatani yang efektif. Oleh karena itu guru memerlukan cara yang dipergunakan untuk mengeskpresikan sehingga peserta didik dapat menerima dan mengalami perubahan kearah yang positif.

Seorang guru yang memahami dirinya, akan mudah menempatkan diri dalam proses belajar mengajar. Mengajar akan memberikan manfaat besar bagi perkembangan peserta didik, peserta didik tidak mengalami kesulitan karena seluruh yang berhubungan dengan proses dikuasai dan digunakan secara tepat oleh guru. Setelah guru mengetahui bahwa dirinya sebagai pendidik akan memainkan perannya untuk membentuk peserta didik menjadi peserta didik yang terdidik. Demikian halnya dengan guru sebagai agen perubahan. Keberadaannya dalam kelas adalah perubahan, kata-katanya, adalah kata yang dapat merubah peserta didik, tingkah lakunya dapat menjadi contoh akan tingkah laku positif bagi peserta didik. Oleh karena itu diri seorang guru adalah pusat perubahan bagi peserta didiknya. 
Adapun keterampilan mengelola kelas dapat dilihat pada dua aspek yaitu; keterampilan yang berhubungan dengan penciptaan dan pemeliharaan kondisi belajar yang optimal (bersifat preventif) dan keterampilan yang berhubungan dengan pengembangan kondisi belajar optimal.

\section{Keterampilan Penciptaan dan Pemeliharaan Kondisi Belajar yang Optimal}

Keterampilan ini berhubungan dengan kompetensi guru dalam mengambil inisiatif dan mengendalikan pembelajaran. Aktivitas yang berkaitan dengan hal tersebut berupa;

\section{Sikap Tanggap}

Sikap tanggap adalah tingkah laku guru bahwa ia hadir bersama dengan mereka (peserta didik). Guru tahu kegiatan mereka, tahu ada perhatian atau tidak ada perhatian, tahu apa yang mereka kerjakan. Guru dapat memantau dan mengetahui apa saja yang terjadi dalam kelas dan dapat mengetahui keadaan peserta didik meskipun guru sedang menulis di papan tulis. Sikap tersebut dapat dilakukan dengan cara; (1) memandang secara saksama. Sikap tersebut mengundang dan melibatkan peserta didik kontak pandang dalam pendekatan guru untuk bercakapcakap, bekerjasama dan menunjukan rasa persahabatan, (2) gerak mendekati. Gerak guru dalam posisi "mendekati kelompok kecil atau individu" 21 menandakan kesiagaan, minat dan perhatian guru yang diberikan terhadap tugas serta aktivitas peserta didik. Gerak mendekati hendaklah dilakukan secara wajar, bukan untuk menakut-nakuti, mengancam atan memberi hukuman, (3) memberi pernyataan. Pernyataan guru terhadap sesuatu yang dikemukakan oleh peserta didik sangat diperlukan, baik berupa tanggapan, komentar, dan lain-lain yang dikenal dengan istilah "umpan balik".22 Akan tetapi haruslah dihindari hal-hal yang menunjukkan dominasi guru seperti dengan komentar atau pernyataan yang mengandung ancaman atau perubahan kondisi psikologis peserta didik karena laku dan sikap guru, (4) memberikan reaksi terhadap "gangguan dalam kelas". ${ }^{23}$ Kelas tidak selamanya tenang. Pasti ada gangguan. Teguran perlu dilakukan oleh guru untuk mengembalikan keadaan kelas yang kondusif. Teguran berarti guru bersama-sama peserta didik. Teguran harus diberikan pada waktu yang tepat dan bermakna. Teguran bukan mematikan kreativitas dan semangat peserta didik akan tetapi dengan teguran peserta didik memahami dirinya dengan mengembangkan krerasi yang dimilikinya sekaligus berbagai motivasi positif dalam pembelajaran. 


\section{Memberikan Perhatian}

Pengelolaan kelas yang efektif, bila guru mampu membagi perhatian kepada berbagai kegiatan yang berlangsung dalam waktu yang sama. Perhatian tersebut dapat dilakukan dengan cara; a) visual yaitu guru dapat mengubah pandangannya dalam memperhatikan kegiatan pertama sedemikian rupa sehingga ia dapat melirik kegiatan kedua, tanpa kehilangan perhatian pada kegiatan pertama. Kontak pandang ini bisa dilakukan terhadap kelompok peserta didik atau peserta didik secara individual, b) verbal yaitu guru dapat memberi komentar, penjelasan, pertanyaan, dan sebagainya terhadap aktivitas peserta didik pertama sementara ia memimpin dan terlibat supervise pada aktivitas peserta didik yang lain.

\section{Pemusatan Perhatian Kelompok}

Guru mengambil inisiatif dan mempertahankan perhatian peserta didik dan memberitahukan bahwa ia bekerjasama dengan kelompok atau sub kelompok yang terdiri dari tiga sampai empat orang. Untuk itu beberapa hal yang dapat dilakukan guru yaitu; a) memberi tanda, b) pertanggungjawaban, c) pengarahan dan petunjuk yang jelas, d) penghentian, e) penguatan f) kelancaran, dan g) kecepatan.

\section{Keterampilan yang Berhubungan dengan Pengembangan Kondisi Belajar yang Optimal}

Keterampilan ini berkaitan dengan tanggapan guru terhadap gangguan peserta didik yang berkelanjutan dengan maksud agar guru dapat mengadakan tindakan-tindakan remedial untuk mengembalikan kondisi belajar yang optimal. Apabila terdapat peserta didik yang menimbulkan gangguan yang berulang-ulang walaupun guru telah menggunakan tingkah laku dan tanggapan yang sesuai, guru dapat meminta bantuan kepala sekolah, konselor sekolah, atau orang tua peserta didik untuk mengatasinya.

Dapat dikatakan bahwa bukanlah kesalahan profesional guru apabila ia tidak dapat menangani setiap masalah peserta didik dalam kelas. Namun pada tingkat tertentu guru dapat menggunakan seperangkat strategi untuk tindakan perbaikan terhadap tingkah laku peserta didik yang terus menerus menimbulkan gangguan yang tidak mau terlibat dalam tugas di kelas. Strategi yang dapat dilakukan oleh guru dalam mengatasi suasana kelas yaitu; a) modifikasi tingkah laku yaitu guru menganalisis tingkah laku peserta didik yang mengalami masalah atau kesulitan dan berusaha memodifikasi tingkah laku tersebut dengan mengaplikasikan pemberian penguatan secara sistematis, b) pendekatan pemecahan masalah kelompok. 
Pendekatan pemecahan masalah dengan cara; memperlancar tugas-tugas mengusahakan terjadinya kerja sama yang baik dalam pelaksanaan tugas. Dapat pula dengan memelihara kegiatan kelompok, memelihara dan memulihkan semangat peserta didik serta menangai konflik yang timbul, c) menemukan dan memecahkan tingkah laku yang menimbulkan masalah. Guru dapat menggunakan seperangkat cara untuk mengendalikan tingkah laku keliru yang muncul, ia dapat mengetahui sebab-sebab yang mengakibatkan ketidakpatuhan tingkah laku tersebut serta berusaha untuk menemukan pemecahannya.

\section{IMPLEMENTASI PENGELOLAAN PROSES PEMBELAJARAN}

Pembelajaran merupakan suatu peristilahan sebagai pengembangan atau inovasi dari belajar. Keduanya memiliki fokus yang berbeda dan ciri yang memperlihatkan nilai progres pendidikan. Perubahan tersebut agar proses belajar selalu memberikan nuansa baru terhadap peserta didik untuk mewujudkan pendidikan yang mengkondisikan peserta didik untuk mengenal dan mengungkapkan kehidupan nyata secara kritis. ${ }^{24}$ Pembelajaran secara simple dapat diartikan sebagai produk interaksi yang berkelanjutan antara pengembangan dan pengalaman hidup. Pesan penting dari konsep tersebut adalah pembelajaran itu, memiliki makna bahwa belajar bagi peserta didik tidak hanya berlangsung pada saat tertentu akan tetapi pembelajaran harus berlangsung sepanjang hidup atau "pendidikan seumur hidup" ${ }^{25}$ Pembelajaran adalah sebagai usaha sadar dari seorang guru untuk membelajarkan peserta didiknya (mengarahkan interaksi dengan sumber belajar lainnya) dalam rangka mencapai tujuan yang diharapkan. ${ }^{26}$ Konteks ini menunjukkan bahwa pembelajaran difokuskan pada kualitas interaksi, peserta didik berusaha menemukan formula materi ajar sebagai bahan interaksi verbalis baik dengan guru maupun dengan para peserta didik. Esensi pembelajaran sesungguhnya menumbuhkan daya kreasi peserta didik baik yang berhubungan dengan kedalaman ilmu yang dipahaminya maupun yang berhubungan dengan kerelasi keilmuan.

Hal tersebut berarti terdapat keunggulan tersendiri dari konsep pembelajaran. Paling tidak dalam pembelajaran memperlihatkan karakter tertentu yang membedakan dengan konsep belajar yang lain. Ciri khasnya adalah; 1) menyediakan pengalaman belajar yang mengaitkan pengetahuan baru dengan pengetahuan yang telah dimiliki peserta didik sehingga belajar merupakan pembentukan pengetahuan, 2) menyediakan berbagai macam alternatif pengalaman belajar, 3) mengintegrasikan pembelajaran dengan situasi realistic dan relevan dengan melibatkan pengalaman konkret, 4) memanfaatkan berbagai media agar pembelajaran lebih me- 
narik, 5) melibatkan peserta didik secara emosional dan sosial sebagai upaya penciptaan pembelajaran yang lebih interaktif.

Pembelajaran bukan semata berupa konsep, akan tetapi terimplementasi dalam kegiatan pembelajaran, dapat menjadi panduan, acuan dan kondisi dinamis dalam kegiatan pembelajaran. Implementasi proses pembelajaran yaitu;

\section{Pengelolaan Tempat Belajar}

Tempat belajar sangat erat hubungannya dengan metode pembelajaran yang digunakan oleh guru dalam pembelajaran. Efektivitas pembelajaran dengan daya ukur metodologi ditentukan oleh kualitas tempat belajar yang baik.

Sekolah merupakan sarana yang memberikan kebebasan kepada guru dan peserta didik untuk mengembangkan kreativitas seperti; dinding, tembok, sudut kelas dijadikan tempat untuk meletakkan hasil kreasi peserta didik dan guru sebagai penunjang pembelajaran.

Pengelolaan tempat belajar meliputi pengelolaan beberapa benda atau obyek yang ada dalam ruang belajar seperti; meja, kursi, pajangan sebagai hasil karya peserta didik, perabot sekolah atau sumber belajar yang ada dalam kelas. Pengelolaan meja kursi dalam kelas belajar bisa beraneka ragam tergantung dari efektivitas dan kepentingan pembelajaran untuk menciptakan pembelajaran yang dialogis.

\section{Pengelolaan Peserta Didik}

Biasanya pengelolaan peserta didik dilakukan dalam beragam bentuk seperti individu, kelompok kecil atau klasikal. Pengelolaan peserta didik memerlukan kecermatan dengan memperhatikan jenis kelamin, tujuan kegiatan, keterlibatan peserta didik, waktu belajar, dan ketersediaan sarana/prasarana. Paling tidak guru harus memahami bahwa setiap peserta didik memiliki karakter yang berbeda-beda. Untuk itu, pembelajaran harus dirancang sedemikian rupa sehingga seluruh peserta didik memperoleh peluang yang sama untuk mengembangkan potensinya, hal-hal yang harus diperhatikan yaitu;

\section{Mengenal Karakter Peserta Didik}

Sikap dan karakter tersebut harus dipahami sebagai langkah awal pemberian bimbingan dan penanganan masalah secara benar dan tepat. Terdapat beberapa karakter peserta didik seperti; a) peserta didik pendiam/pemalu. Peserta didik yang pendiam biasanya tidak banyak aktivitasnya, termasuk tidak suka bertanya disaat berlangsungnya pelajaran, 
tetapi ia selalu menurut pada perintah guru. Menghadapi peserta didik seperti ini, guru hendaknya memberikan perhatian dengan memberikan kesempatan untuk bertanya, mengamati dan menganalisis materi ajar. Hal tersebut sebagai upaya untuk mengubah dengan cara bertahap agar peserta didik tersebut dapat lebih aktif dan kreatif, b) peserta didik perenung. Sikapnya suka melamun dan tidak berkonsentrasi dalam mengikuti pelajaran. Kadang-kadang melihat kedepan tetapi tidak memperhatikan pelajaran yang berlangsung. Guru sebaiknya banyak bertanya kepada peserta didik tersebut, banyak memberi perintah dengan berulang-ulang, c) peserta didik yang super aktif. Sikap tersebut biasanya bersifat negatif, mengganggu kondisi belajar teman-temanya dikelas dan merusak konsentrasi. Selain itu, suka berbuat sesuatu yang aneh menarik perhatian teman-temanya dan guru, sehingga kondisi belajar tidak berlangsung secara kondusif. Dalam menghadapi peserta didik tersebut guru hendaknya memberikan bimbingan, konseling dan penangan khusus. Guru hendaknya memahami latar belakang keadaan dirumahnya dan berkonsultasi secara aktif dengan orang tuanya, c) peserta didik malas. Peserta didik pemalas biasanya mengikuti sikap perenung. Gejalanya berupa jarang mengerjakan tugas, pekerjaan rumah, mengabaikan kebersihan kelas, kebersihan diri sendiri, kurang disiplin atau selalu terlambat masuk sekolah. Hal tersebut terjadi disebabkan oleh "minat dan motivasi, kecepatan tahapan belajar, tingkat kemampuan, siklus cara berpikir, dan struktur pengetahuan". ${ }^{27}$

Pembelajaran memiliki makna penting yaitu menambah pengetahuan peserta didik dengan berbagai macam perbedaan dan kecekatan pembelajaran. Kesempurnaan pengetahuannya pasti berbeda-beda antara satu peserta didik dengan peserta didik lainnya, dibedakan oleh kemampuan dan kualitas perhatian yang dimiliki peserta didik. Selain pembelajaran sebagai sarana penting mengubah sikap diri, pemalas menjadi kreatif, super aktif yang dapat mengarah pada aspek positif.

\section{Belajar Klasik (Individu dan Kelompok)}

Pembelajaran klasik artinya guru memberi penjelasan dan perintah pada seluruh peserta didik duduk secara klasikal sambil mengikuti proses belajar".28 Sejak awal pembelajaran guru harus memahami dan mempelajari keadaan, sikap dan perilaku peserta didik secara individu. Pendekatan individu berlangsung dalam kelas, sebagai upaya memahami lebih sempurna keadaan dan problema peserta didik terutama yang berkaitan dengan proses belajar. 
Pada saat guru memberikan tugas sebaiknya guru mendatangi peserta didik secara individu untuk memahami kelebihan dan kelemahan yang dimiliki peserta didik. Kelemahan dan kelebihan tersebut sebagai bahan penting untuk melakukan perbaikan-perbaikan pembelajaran.

\section{Mengaktifkan Peserta Didik}

Dalam mengelola kegiatan pembelajaran, guru perlu merencanakan tugas dan alat belajar yang menantang, memberikan umpan balik, belajar kelompok dan menyediakan program penilaian yang memungkinkan semua peserta didik mampu unjuk kemampuan/mendemonstrasikan kinerja (performance) sebagai hasil belajar.

Dengan demikian, strategi yang perlu dikuasai guru dalam pengelolaan pembelajaran yaitu; (1) penyediaan pertanyaan yang mendorong berpikir produktif, (2) menyediakan umpan balik yang brermakna, (3) belajar kelompok, (4) penyediaan penilaian, (5). Mengembangkan pembelajaran melalui peta konsep" ${ }^{29}$

Pertama, penyediaan pertanyaan. Alat pembelajaran yang paling murah tetapi ampuh adalah pertanyaan. Pertanyaan membuat peserta didik berpikir, merangsang apresiasi dan daya pikir. Merangsang berpikir artinya meransang peserta didik menggunakan gagasan yang sudah dikemukakan oleh guru. Kedua, menyediakan umpan balik yang bermakna artinya respons guru terhadap perilaku peserta didik. Respons berupa, tanggapan yang disampaikan guru ketika peserta didik bertanya, berpendapat, menunjukan hasil kerja dan membuat kesalahan. Umpan balik guru terhadap peserta didik tidak mengandung makna memvonis, tetapi sebagai alternatif dari keadaan yang dihadapi peserta didik.

Ketiga, belajar kelompok. Suatu cara untuk mengaktifkan peserta didik yaitu dengan belajar kelompok. Bila peserta didik belum terbiasa bekerja efektif dalam kelompok, guru hendaknya memberikan tugas dengan mempertimbangkan seperti; kelompok kecil (dua sampai tiga orang peserta didik) dan guru menetapkan anggota kelompoknya, tugas bersifat sederhana, sehingga dapat diselesaikan dalam waktu singkat, perintah guru jelas dan menyelesaikan dengan bertahap, guru perlu menyediakan sumber belajar dan guru menjelaskan peran setiap peserta didik. Cara lain yang perlu dikembangkan oleh guru adalah curah pendapat (brainstorming). Kegiatan ini perlu dikendalikan oleh guru, tetapi guru tidak boleh membatasi gagasan-gagasan peserta didik. Guru berkeyakinan bahwa semua peserta didik dalam kelas dapat menyumbangkan gagasangagasannya secara bebas dan leluasa. Brainstorming diperlukan dalam rangka mendorong guru menemukan perubahan pengetahuan peserta 
didik tentang topik sebelum kelas mulai mengerjakannya, sehingga guru dapat merencanakan urutan pembelajaran selanjutnya.

Keempat, penilaian terhadap performance. Istilah lain dari penilaian adalah evaluasi. "Evaluasi artinya pengumpulan kenyataan secara sistematik untuk menetapkan apakah dalam kenyataannya terjadi perubahan dalam diri peserta didik dan menetapkan sejauhmana tingkat perubahan dalam pribadi peserta didik". ${ }^{30}$ Informasi tersebut diperlukan oleh guru agar dapat menentukan tugas atau kegiatan yang harus diberikan kepada peserta didik agar pengetahuan, kemampuan dan sikap mereka lebih berkembang. Oleh karena itu, penilaian sebaiknya dilakukan secara alami pada saat guru mengajar, tidak diadakan secara khusus, dalam waktu yang khusus dan terpisah dari kegiatan belajar mengajar.

Kelima, pengembangan pembelajaran melalui peta konsep. Peta konsep adalah cara menyatakan hubungan yang bermakna antara konsep dalam bentuk preposisi-preposisi. ${ }^{31}$ Peta konsep digunakan; 1) untuk membantu guru mengetahui kemajuan yang telah dicapai peserta didik terhadap topik bahasan, 2) menyediakan titik tolak untuk "diskusi" 32 antara peserta didik. Peserta didik akan ditempatkan dalam kelompok (dua atau tiga orang) untuk membangun peta melalui mufakat, 3) memberi umpan balik dari perkembangan dan kemajuan pengetahuan peserta didik. Peta konsep tentu diselesaikan sebagai kegiatan akhir dalam urutan pengajaran tentang suatu topik. Peserta didik dapat diberi konsep kunci dari suatu topik dan meminta mereka menghubungkannya dalam suatu peta konsep, 4) mengaitkan gagasan-gagasan dan pengertian yang dikembangkan dalam suatu kegiatan dengan apa yang mereka pelajari dalam kegiatan lain. Untuk maksud ini, guru memberi peserta didik dua buah daftar kunci, satu daftar dari setiap topik dan meminta peserta didik mengumpulkan kata-kata dari kedua daftar dalam peta konsep mereka.

\section{KESIMPULAN}

1. Kelas harus dikelola karena kelas tempat transformasi, interaksi untuk pematangan kemampuan personal dan sosial.

2. Kelas harus dikelola karena peserta didik yang beragam.

3. Mengelola kelas berkaitan dengan keterampilan memelihara kelas yang kondusif dan mengembangkan menjadi produktif.

4. Mengelola kelas berarti menyediakan fasilitas untuk mewujudkan kelas yang tertib.

5. Mengelola kelas berkaitan dengan tempat belajar, mengelola peserta didik secara personal dan kelompok. 


\section{CATATAN AKHIR}

1. Fuad Ihsan, Dasar-dasar Kependidikan, Cet III, Jakarta: Rineka Cipta, 2003, h. 11.

2. Zamroni, Pendidikan Demokrasi dalam Transisi, Cet, I, Jakarta: Pustaka Nasional, 2007, h. 96

3. Ibid, h. 98.

4. Amir Tengku Ramly, Memompa Tehnik Pengajaran menjadi Guru Kaya, Cet II, Jakarta: Kawan Pustaka, 2006, h. 86.

5. Karakter berasal dari bahasa Yunani charas sein yang berarti mula-mula coretan atau goresan. Kemudian berarti ditempel atau gambaran yang ditinggalkan oleh tempelan itu. Agus Sujanto, Psikologi Umum, Cet IX, Jakarta: Bumi Aksara, 2001, h.101.

6. Muhammad Surya, Psikologi Pembelajaran dan Pengajaran, Cet. I, Bandung: Pustaka Bani Quraisy, 2004, h.56.

7. Saiful Bahri Djamarah, Strategi Belajar Mengajar, Cet III, Jakarta: Rineka Cipta, 2006, h.175.

8. Ibid, h. 175.

9. Ibid, h. 176

10. Ibid, h. 173.

11. Syaiful Sagala, Konsep dan Makna Pembelajaran, Cet VI, Bandung: Alpabeta, 2008, h. 123.

12. Oemar Hamalik, Proses Belajar Mengajar, Cet X, Jakarta: Bumi Aksara, 2009, h. 52.

13. Martinis Yamin, Manajemen Pembelajaran Kelas, Cet I, Jakarta: Gaung Persada, 2009, h. 34 .

14. Lihat, Saiful Bahri Djamarah, Guru dan Anak Didik dalam Interalksi Edukatif, Cet. II, Jakarta: Rineka Cipta, 2005, h. 172.

15. Ainurraahman, Belajar dan Pembelajaran, Cet III, Bandung: Alfabeta, 2009, h. 13.

16. Syaiful Bahri Djamarah, op.cit., h. 178.

17. Suharsimi Arikunto, Pengelolaan Kelas dan Siswa Sebuah Pendekatan Evaluatif, Cet. II, Jakarta: Rajawali, 1988, h. 21.

18. Sudarman Danim, Inovasi Pendidikan, Cet I, Bandung: Pustaka Setia, 2002, h. 15.

19. Martinis Yasmin, op.cit., h. 104.

20. Zulkifli, Psikologi Perkembangan, Cet. VIII, Bandung: Remaja Rosdakarya, 2001, h.15.

21. Nasution, Berbagai Pendekatan dalam Proses Belajar dan Mengajar, Cet. XIII, Jakarta; Bumi Aksara, 2009, h. 76.

22. Syaiful Bahri Djamarah, op.cit., h. 142.

23. Syaiful Bahri Djamarah, ibid., h. 174.

24. Sudarman Danim, op.cit., h. 15.

25. Hasbullah, Dasar-dasar Pendidikan, Cet. IV, Jakarta: Raja Grapindo Persada, 2005, h. 66.

26. Trianto, Desain Model Pembelajaran Inovatif Progresif, Cet I, Jakarta: Prenada Media Group, 2009, h. 17.

27. Martinis Yatim, op.cit., h. 170.

28. Ibid., h. 171.

29. Ibid., h. 173. 
30. Daryanto, Evaluasi Pendidikan, Cet. V, Jakarta: Rineka Cipta, 2008, h. 1.

31. Martinis Yamin, op.cit., h. 178.

32. Ibid., h. 178.

\section{DAFTAR PUSTAKA}

Ainurraahman, Belajar dan Pembelajaran, Cet. III, Bandung: Alfabeta, 2009.

Arikunto, Suharsimi, Pengelolaan Kelas dan Siswa Sebuah Pendekatan Evaluatif, Cet. II Jakarta: Rajawali, 1988.

Bahri Djamarah, Saiful, Strategi Belajar Mengajar, Cet. III, Jakarta: Rineka Cipta, 2006. Rineka Cipta, 2005.

Guru dan Anak Didik dalam Interalksi Edukatif, Cet. II, Jakarta:

Danim, Sudarman, Inovasi Pendidikan, Cet I, Bandung: Pustaka Setia, 2002.

Daryanto, Evaluasi Pendidikan, Cet V, Jakarta: Rineka Cipta, 2008.

Hamalik, Oemar, Proses Belajar Mengajar, Cet X, Jakarta: Bumi Aksara, 2009.

Hasbullah, Dasar-dasar Pendidikan, Cet. IV, Jakarta: Raja Grapindo Persada, 2005.

Nasution, Berbagai Pendekatan dalam Proses Belajar dan Mengajar, Cet. XIII, Jakarta; Bumi Aksara, 2009.

Sagala, Saiful, Konsep dan Makna Pembelajaran, Cet. VI, Bandung: Alpabeta, 2008.

Sujanto, Agus, Psikologi Umum, Cet. IX, Jakarta: Bumi Aksara, 2001.

Surya, Muhammad, Psikologi Pembelajaran dan Pengajaran, Cet. I, Bandung: Pustaka Bani Quraisy, 2004.

Trianto, Desain Model Pembelajaran Inovatif Progresif, Cet. I, Jakarta: Prenada Media Grup, 2009.

Yamin, Martinis, Manajemen Pembelajaran Kelas, Cet I, Jakarta: Gaung Persada, 2009.

Zulkifli, Psikologi Perkembangan, Cet. VIII, Bandung: Remaja Rosdakarya, 2001. 